\title{
Pemilihan Siswa-Siswi Berprestasi Menggunakan Metode Weighted Product (WP) Studi Kasus SMP-Al Fitroh Tangerang
}

\author{
Taufik Hidayat $^{1}$, Siti Komariah ${ }^{2}$ \\ 1,2 Jurusan Teknik Informatika FT Universitas Islam Syekh Yusuf \\ ${ }^{1.2}$ Jln. Maulana Yusuf No.10 Babakan,Kota Tangerang 15118 \\ 1thidayat@unis.ac.id \\ ${ }^{2}$ sitikomariahmiraldi@gmail.com
}

\begin{abstract}
Intisari- Sistem Pendukung Keputusan (SPK) merupakan sistem informasi, pemodelan, dan pemanipulasi data.Sistem itu digunakan untuk membantu pengambilan keputusan dalam situasi yang semiterstuktur dan situasi yang tidak terstruktur, dimana tak seorang pun tahu secara pasti bagaimana keputusan seharusnya dibuat. Sistem pendukung keputusan dapat dihasilkan dengan menggunakan beberapa macam metode, salah satu diantaranya adalah Metode Weighted Product (WP). Metode Weighted Product (WP) adalah merupakan metode yang mengunakan perkalian untuk menghubungkan rating atribut, di mana rating setiap atribut harus dipangkatkan terlebih dahulu dengan bobot atribut yang bersangkutan. Proses ini sama halnya dengan proses normalisasi. Proses SPK untuk menentukan penerima beasiswa.Dengan menggunakan Sistem Pendukung Keputusan dan database, data beasiswa di SMP AL-FITROH Tangerang dapat disimpan di dalamnya, sehingga jika terjadi kesalahan dalam penginputan nilai atau data beasiswa, maka data yang salah tersebut dapat diperbaiki tanpa harus menginput data ulang data beasiswa. Beasiswa adalah pemberian berupa bantuan keuangan yang diberikan kepada perorangan yang bertujuan untuk digunakan demi keberlangsungan pendidikan yang ditempuh. Metodologi penelitian yang digunakan dalam pembuatan sistem penerimaan siswa-siswi berprestasi adalah metode waterfall yang meliputi sistem enginering, analysis, design, coding dan testing. Aplikasi ini dibuat dengan menggunakan bahasa pemrograman PHP (Hypertext Preprocessor), framework menggunakan code integer, Xampp web server.
\end{abstract}

Kata kunci- Pemilihan Siswa-Siswi Berprestasi Menggunakan Metode Weighted Product

Abstract - Decision Support System (SPK) is a system of information, modeling, and manipulation of data. The system is used to help decision making in semi-structured and unstructured situations, where no one knows for sure how decisions should be made. Decision support systems can be generated using several methods, one of which is the Weighted Product (WP) Method. Weighted Product (WP) method is a method that uses multiplication to connect attribute ratings, where the rating of each attribute must be raised first with the weight of the attribute in question. This process is the same as the normalization process. SPK process to determine scholarship recipients. Using Decision Support Systems and databases, scholarship data at Tangerang AL-FITROH Middle School can be stored in it, so that if there is an error in inputting grades or scholarship data, then the wrong data can be corrected without having to input the data scholarship data reset. Scholarships are gifts in the form of financial assistance given to individuals who aim to be used for the continuity of the education being pursued. The research methodology used in making the admissions system for high achieving students is the waterfall method which includes engineering, analysis, design, coding and testing systems. This application is created using the PHP (Hypertext Preprocessor) programming language, the framework uses integer code, Xampp web server.

Keywords — Student Achievement Selection Using the Weighted Product Method

\section{PENDAhUluan}

Siswa berprestasi memiliki skala ukur ter lalu sempit. Hanya terbatas pada kemampuan siswa dalam bidang kognitif (intelektual). Siapa yang menunjukan hasil belajar terbaik maka mereka dikatakan sebagai seorang siswa berprestasi. Namun tidak ada jaminan kalua siswa berprestasi itu akan menjadi siswa teladan disekolahnya.
Lebih jauh mungkin dapat diungkapakan bahwa siswa berprestasi lebih cenderung berorientasi pada prestasi akademis. Hasil belajar dari semuah mata pelajaran di sekolah setelah diadakan ujian. Atau hasil belajar pada prestasi kegiatan ekstrakurikuler seperti seni, dan budaya.

Beasiswa dapat dikatakan sebagai pembiayaan yang tidak bersumber dari pendanaan sendiri atau orang tua. Akan tetapi diberikan oleh pemerintah, 
perusahaan swasta, serta lembaga pendidikan atau peneliti.Biaya tersebut diberikan kepada yang berhak menerima, berdasarkan klasifikasi kualitas dan kompetensi penerima beasiswa.

Model yang digunakandalam system aplikasi pendukung keputusan ini adalah Weighted Product Decision Making (WPDM) dengan metode weighted product. Metode weighted product ini dipilih karna metode tersebut menentukan nilai bobot untuk setiap atribut. Kemudian dilanjutkan dengan peroses pemeringkatan yang akan menyeleksi alternatif terbaik dari sejumlah alternative.

\section{Metodologi Penelitian}

\section{A. Sistem Pendukung Keputusan}

Suatu sistem yang bekerja untuk melakukan suatu tindakan dalam pengambilan suatu keputusan dimana objeknya memiliki kriteria-kriteria yang akan diolah kedalam metode. Metode Weighted Product merupakan bagian dari konsep MultiAttibut Decision Making (MADM) dimana diperlukan normalisasi pada perhitungannya, karena instansi cukup memilih beberapa barang yang akan menjadi alternatif pemilihan dan memberikan nilai bobot pada perbandingan alternatif dan kriterianya[1].

Sistem Pendukung Keputusan merupakan sistem informasi interaktif yang menyediakan informasi, pemodelan, dan manipulasi data. SPK dirancang untuk mendukung seluruh tahap pengambilan keputusan mulai dari mengidentifikasi masalah, memilih data yang relevan, dan menentukan pendekatan yang digunakan dalam proses pengambilan keputusan, sampai mengevakuasi pemilihan alternatif. Sistem itu digunakan untuk membantu pengambilan keputusan dalam situasi yang semi terstruktur dan situasi yang terstruktur, dimana tak seorang pun tahu secara pasti bagaimana keputusan seharusnya dibuat (Philip Kotler dan Gary Amstrong (2006: 179)[2].

Langkah - langkah yang diperlukan dalam proses pengambilan keputusan (Basyaib, 2006) adalah : a. Intelijen

1) Pembentukan persepsi terhadap situasi yang dihadapi Ialah mengenali situasi keputusan dan pendefinisian karakteristik utama yang ada pada situasi tersebut

2) Membangun model yang mewakili situasi Sebuah model merupakan kendaraan yang membantu dalam mengestimasi hasil yang mungkin terjadi dari sebuah situasi keputusan

3) Penentuan ukuran kuantitatif terhadap biaya (disbenefits) dan manfaat yang paling tepat untuk situasi yang dihadapi Sistem ukuran seragam yang akan digunakan dalam membandingkan alternatif langkah keputusan

b. Desain Penentuan dengan spesifik alternatif yang dimiliki dengan mengenali dan merumuskan dengan jelas langkah - langkah yang mungkin dilakukan.

c. Pilihan

1) Evaluasi manfaat dan biaya (disbenefits) dari semua langkah alternatif. Ialah penilaian akibat penerapan setiap langkah alternatif dengan menggunakan ukuran biaya dan manfaat.

2) Menetapkan kriteria dalam memilih langkahterbaik Adalah penetapan peraturan dengan mengaitkan hasil dengan tujuan pembuatan keputusan.

3) Penyelesaian situasikeputusan Ialah mengambil sebuah langkah dengan dasar kriteria yang dapat diterima. Langkah langkah diatas dapat dilakukan secara berulang, baik seluruh langkah maupun sebagian. Hal tersebut dilaksanakan terus menerus hingga situasi keputusan benarbenarterselesaikan (Suryadi, K. dan M.Ali Ramdhani, "Sistem Pendukung Keputusan", Bandung : PTRemaja Rosdakarya, 2012. Sarika,)[3].

- Preferensi untuk alternative Ai diberikan sebagai berikut:

$$
S i=\prod_{j=1}^{n} x_{i j} w j
$$




$$
\mathrm{W}_{\mathrm{J}}=\frac{w_{j}}{\Sigma w_{j}}
$$

$\mathrm{S}$ :Menyatakan preferensi alternative dianalogikan sebagai vector $\mathrm{S}$

$\mathrm{X}$ : Menyatakan nilai kriteria

W :Menyatakan bobot kriteria / subkriteria

i : Menyatakan alternatif

j : Menyatakan kriteria

$\mathrm{n} \quad$ : Menyatakan banyaknya kriteria

$\mathrm{Wj}$ adalah pangkat bernilai positif untuk atribut keuntungan, dan bernilai negatif untuk atribut biaya. preferensi relative dari setiap alternative diberikan sebagai berikut:

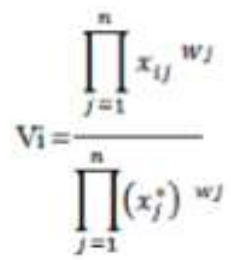

$\mathrm{V}=$ menyatakan preferensi alternative dianalogikan sebagai vector $\mathrm{V}$

$\mathrm{X}=$ menyatakan nilai kriteria

$\mathrm{W}=$ menyatakan bobot kriteria

$\mathrm{i}=$ menyatakan alternatif

$\mathrm{j} \quad=$ menyatakan kriteria

$\mathrm{n} \quad=$ menyatakan banyaknya kriteria

* = menyatakan banyaknya criteria yang telah dinilai pada vector

Ranting kecocokan setiap alternatif pada setiap kriteria, dinilai dengan 1 sampai 5 yaitu :

$$
\begin{aligned}
& 1=\text { Sangat buruk } \\
& 2=\text { buruk } \\
& 3=\text { cukup } \\
& 4=\text { baik } \\
& 5=\text { sangat baik }
\end{aligned}
$$

\begin{tabular}{|c|c|c|c|c|c|}
\hline No & Kode & Kriteria & Skala & Nila & Bobot \\
\hline 1 & C1 & $\begin{array}{l}\text { Nilai rata- } \\
\text { rata }\end{array}$ & $\begin{array}{l}100-91 \\
90-81 \\
80-71 \\
70-61 \\
60-51\end{array}$ & $\begin{array}{l}5 \\
4 \\
3 \\
2 \\
1\end{array}$ & 50 \\
\hline 2 & C2 & Kehadiran & $\begin{array}{l}\text { Sangat } \\
\text { rajin } \\
\text { Rajin } \\
\text { Kurang } \\
\text { Rajin } \\
\text { Jarang } \\
\text { Tidak } \\
\text { sama } \\
\text { sekali }\end{array}$ & $\begin{array}{l}5 \\
4 \\
3 \\
2 \\
1\end{array}$ & 40 \\
\hline 3 & $\mathrm{C} 3$ & $\begin{array}{l}\text { Aktif } \\
\text { organisasi }\end{array}$ & $\begin{array}{l}\text { Sangat } \\
\text { aktif } \\
\text { Aktif } \\
\text { Sedang } \\
\text { Jarang } \\
\text { aktif } \\
\text { Tidak } \\
\text { aktif }\end{array}$ & $\begin{array}{l}5 \\
4 \\
3 \\
2 \\
1\end{array}$ & 30 \\
\hline
\end{tabular}

Rating kepentingan setiap kriteria dinilai dengan 1 sampai 5 yaitu :

$$
\begin{aligned}
& 1=\text { Sangat rendah } \\
& 2=\text { rendah } \\
& 3=\text { cukup } \\
& 4=\text { tinggi } \\
& 5=\text { sangat tinggi }
\end{aligned}
$$

Tabel 1. Tabel Instrumen

B. Instrumen Penelitian

Penelitian ini menggunakan data sekunder berupa nama calon siswa-siswi brprestasi di sekolah dan data kriteria yang digunakan sebagi instrumentasi guna mamperoleh data dalam proses pemilihan siswa-siswa berprestasi.

\section{HASIL DAN PEMBAHASAN}

Metode Weighted product (WP) dalam sistem pemeringkatan sebagaimana ditunjukan sebagai sample dalam pengujian eksperimen pemeringkatan. Weighted Product (WP) adalah suatu metode yang menggunakan perkalian untuk menghubungkan rating atribut, di mana rating setiap atribut harus dipangkatkan dulu dengan bobot yang bersangkutan. Proses ini sama halnya dengan proses normalisasi. Weighted Product (WP) merupakan salah satu metode yang digunakan untuk menyelesaikan masalah Multi Attribute Decision Making (MADM). MADM adalah suatu metode yang digunakan untuk mencari alternatif paling optimal dari sejumlah alternatif optimal dengan kriteria tertentu. Inti dari MADM adalah menentukan nilai bobot untuk setiap 
atribut, kemudian dilanjutkan dengan proses perangkingan yang akan menyeleksi alternatif yang sudah diberikan[2]. Kriteria yang digunakan dalam sistem pendukung keputusan pemilihan siswa-siswi berprestasi yaitu :
C1 = Nilai Rata-Rata
$\mathrm{C} 2=$ Kehadiran
$\mathrm{C} 3=$ Aktif Organisasi

Ada 4 calon penduduk yang akan menjadi alternatif, yaitu :
$\mathrm{A} 1=$ Dinda
$\mathrm{A} 2=$ Aulia
A3 = Sandi
A4 = Rian

Tabel-tabel kriteria dengan bobotnya masingmasing dapat dilihat pada tabel berikut :

1. Tabel nilai rata-rata

\begin{tabular}{|c|c|c|}
\hline $\begin{array}{c}\text { Nilai } \\
\text { rata-rata }\end{array}$ & Nilai & Bobot \\
\hline $100-91$ & 50 & \\
\hline $90-81$ & 40 & \\
\hline $80-71$ & 30 & \multirow{2}{*}{50} \\
\hline $70-61$ & 20 & \\
\hline $60-51$ & 11 & \\
\hline
\end{tabular}

2. Tabel kehadiran

\begin{tabular}{|c|c|c|}
\hline Kehadiran & Nilai & Bobot \\
\hline Sangat rajin & 50 & \\
\hline Rajin & 40 & \\
\hline Kurang Rajin & 30 & \multirow{2}{*}{40} \\
Jarang & 20 & \\
Tidak sama & 10 & \\
sekali & & \\
\hline
\end{tabular}

\section{Aktif Organisasi}

\begin{tabular}{|c|c|c|}
\hline Aktif Organisasi & Nilai & Bobot \\
\hline Sangat aktif & 50 & \\
\cline { 1 - 2 } Aktif & 40 & \multirow{2}{*}{20} \\
\cline { 1 - 2 } Sedang & 30 & \\
\cline { 1 - 2 } Jarang aktif & 20 \\
\cline { 1 - 2 } Tidak aktif & 10 & \\
\hline
\end{tabular}

Berikut ini adalah tabel kecocokan setiap alternative pada setiap kriteria, yaitu Rating kecocokan setiap alternatif pada setiap kriteria.

Tabel 2. Tabel Kecocokan

\begin{tabular}{|c|c|c|c|}
\hline \multirow{2}{*}{$\begin{array}{l}\text { Altemative } \\
\text { (nama siswa-siswi) }\end{array}$} & \multicolumn{3}{|c|}{ Kriteria } \\
\cline { 2 - 4 } & $\mathrm{Cl}$ & $\mathrm{C} 2$ & $\mathrm{C} 3$ \\
\hline Dinda & 5 & 4 & 3 \\
\hline Auliah & 4 & 5 & 2 \\
\hline Sandi & 1 & 4 & 5 \\
\hline Rian & 3 & 5 & 4 \\
\hline
\end{tabular}

Dengan nilai bobot preferensi sebagai berikut : $\mathrm{W}=50,40,30$

Untuk mendapatkan hasil terlebih dahulu dilakukan perbaikan bobot maka dapat perhitungan sebagai berikut dengan rumus :

$$
\begin{gathered}
W j=\frac{W j}{\sum W j} \\
\mathrm{~W} 1=\frac{50}{50+40+30}=\frac{50}{120}=0.41 \\
\mathrm{~W} 2=\frac{40}{50+40+30}=\frac{40}{120}=0.33 \\
\mathrm{~W} 3=\frac{30}{50+40+30}=\frac{30}{120}=0.25
\end{gathered}
$$

Langkah berikutnya yaitu menghitung vektor S, dimana data yang ada akan dikalikan tetapi sebelumnya akan dilakukan pemangkatan bobot dari masing-masing kriteria. 


$$
\begin{gathered}
S i=\prod_{j=1}^{n} x_{i j} w_{j} \\
S_{1}=\left(5^{0.41}\right)\left(4^{0.33}\right)\left(3^{0.25}\right)=4.12 \\
S_{2}=\left(4^{0.41}\right)\left(5^{0.33}\right)\left(2^{0.25}\right)=3.79 \\
S_{3}=\left(1^{0.41}\right)\left(4^{0.33}\right)\left(5^{0.25}\right)=2.98 \\
S_{4}=\left(3^{0.41}\right)\left(5^{0.33}\right)\left(4^{0.25}\right)=3.88
\end{gathered}
$$

Setelah masing-masing Vektor $\mathrm{S}$ mendapatkan nilainya, langkah selanjutnya adalah menjumlahkan vektor $\mathrm{S}$ untuk menghitung vektor $\mathrm{V}$ yang akan digunakan untuk perangkingan. Sederhananya:

$$
\begin{aligned}
\boldsymbol{V}_{i}=\frac{\prod_{j=1}^{n} X_{i j w j}}{\prod_{j=1}^{n}\left(X_{j}^{*}\right)_{w j}} \quad V_{1}=\frac{S_{i}}{S_{1}+S_{2}+S_{3}+S_{4}} \\
V_{1}=\frac{4.12}{14.77}=0.27 \\
V_{2}=\frac{3.79}{14.77}=0.25 \\
V_{3}=\frac{2.98}{14.77}=0.20 \\
V_{4}=\frac{3.88}{14.77}=0.26
\end{aligned}
$$

Sehingga nilai akhir yang diperoleh masing-masing alternatif dalam perangkingan adalah sebagai berikut:
Tabel 3. Perangkingan (Output)

\begin{tabular}{|c|c|c|}
\hline $\begin{array}{c}\text { Alternatif } \\
\text { (Vektor) }\end{array}$ & Nilai & Rangking \\
\hline Alternatif 1 (V1) & 0.27 & 1 \\
\hline Alternatif 4 (V4) & 0.26 & 2 \\
\hline Alternatif 2 (V2) & 0.25 & 3 \\
\hline Alternatif 3 (V3) & 0.20 & 4 \\
\hline
\end{tabular}

\section{KESIMPULAN}

Kesimpulan Setelah dilakukan analisis, perancangan, implementasi serta pengujian pada bab-bab sebelumnya, maka dapat diperoleh kesimpulan terhadap Sistem Pendukung Keputusan Penerima beasiswa di smp al-fitro kota Tangerang adalah sebagai berikut :

1. Pada penelitian ini Metode Weighted Product (WP) dapat diterapkan untuk menyeleksi siswa-siswi berprestasi

2. Untuk menerapkan pemilihan siswa siswi berprestasi secara online dengan disebarkan kedalam kelas-kelas.

\section{REFERENSI}

[1] T. Hidayat and Y. K. Hasim, "Model Multi-Attribut Decission Making ( MADM ) Untuk Penilaian Kinerja Dosen Menggunakan Metode Weighted Product," pp. 37-42.

[2] W. Suharso et al., "Sistem Pendukung Keputusan Pemilihan Laptop Pada E-Commerce Menggunakan Metode Weighted Product," Semin. Nas. Teknol. dan Rekayasa 2019, pp. 43-53, 2019.

[3] S. Solikhun, "Perbandingan Metode Weighted Product Dan Weighted Sum Model Dalam Pemilihan Perguruan Swasta Terbaik Jurusan Komputer," Klik - Kumpul. J. Ilmu Komput., vol. 4, no. 1, p. $70,2017$. 